\title{
Toxic effects of latex and Tygon tubing on marine phytoplankton, zooplankton and bacteria
}

\author{
N. M. Price ${ }^{1}$, P. J. Harrison ${ }^{1}$, M. R. Landry ${ }^{2}$, F. Azam ${ }^{3}$ \& K. J. F. Hall ${ }^{4}$ \\ ${ }^{1}$ Depts. of Botany and Oceanography, University of British Columbia,Vancouver, British Columbia V6T 2B1, Canada \\ ${ }^{2}$ School of Oceanography, University of Washington, Seattle, Washington 98195, USA \\ ${ }^{3}$ Scripps Institution of Oceanography, University of California, La Jolla, California 92093, USA \\ ${ }^{4}$ Westwater Research Centre and Department of Civil Engineering, University of British Columbia, Vancouver, British \\ Columbia V6T 1W5, Canada
}

\begin{abstract}
Natural plankton assemblages were incubated with a small piece of silicone, Tygon or latex rubber tubing in $200 \mathrm{ml}$ of culture to determine potential long-term toxic effects of the tubing. Drastic decreases in cell numbers and chlorophyll fluorescence indicated that over $95 \%$ of the phytoplankton were killed by the latex rubber tubing in $4 \mathrm{~d}$. Even a $1 \mathrm{~mm}$ piece of latex tubing killed $\sim 90 \%$ of the phytoplankton. The most resistant species were Thalassiosira spp. and pennate diatoms. Growth of heterotrophic bodonid flagellates was unaffected by small amounts of latex tubing $(1 \mathrm{~mm})$ and larger pieces decreased growth only marginally. Bacterial numbers decreased initially, but resistant forms began to grow at the end of the experiment. New unwashed Tygon tubing significantly decreased phytoplankton growth rates, but much less than latex tubing. Washing Tygon tubing, by pouring as little as $200 \mathrm{ml}$ of seawater through a $1 \mathrm{~m}$ piece of $0.6 \mathrm{~cm}$ diameter tubing, removed this toxic effect. No inhibitory effects were found with silicone tubing. Short-term effects of the presence of tubing in the culture medium were documented by measuring phytoplankton photosynthetic rates $\left({ }^{14} \mathrm{C}\right.$ uptake) and ${ }^{3} \mathrm{H}$-thymidine incorporation into bacteria. Latex and unwashed Tygon tubing significantly decreased these metabolic rate processes. Tubing effects on zooplankton survival, fecundity and egg viability were tested for the copepod Acartia clausij. Latex tubing had the largest effect on these parameters followed by Tygon tubing. Silicone tubing exerted no significant effect.
\end{abstract}

\section{INTRODUCTION}

During the period of rapid advancement in marine phytoplankton culture techniques in the 1950's and 60 's a great deal of effort was focussed on different artificial media and their elemental components. These studies provided an early realization that certain materials used in culturing could be toxic to algal growth (Davis et al. 1953, Doty \& Oguri 1959, Dyer \& Richardson 1962, Ryther \& Guillard 1962, Bernhard et al. 1966, Brooks 1969, Bernhard \& Zattera 1970). In subsequent years, over 50 different materials, mainly plastics, rubbers, metals and alloys were tested for toxicity effects (Bernhard et al. 1966, Bernhard 1977). Natural rubbers, some polyvinyl chlorides, and some copper-containing alloys were found to inhibit phytoplankton growth (Bernhard et al. 1966).

Today many of the obviously toxic materials identified in these earlier studies are avoided, especially if they would be used in contact with organisms for an extended period of time. Nevertheless, certain of these materials find their way into use under a variety of subtle circumstances. Latex rubber tubing, for example, has a long history as an internal closure spring in Van Dorn and Niskin water-bottle samplers. Short pieces of rubber tubing are also frequently used to drain water bottles or as outlet tubes for flow-through seawater systems. In these applications the user might assume that the exposure of the seawater to the potentially toxic tubing is so brief that the resulting contamination is negligible. More generally, the user may not fully appreciate how toxic the materials can be in brief or limited surface area exposure and may therefore decide to employ lower cost, but potentially harmful materials in large-scale culturing or experimental systems.

Our awareness of and interest in tubing toxicity developed during a course on phytoplankton, zooplankton and bacteria interactions at the Friday Harbor Laboratory during summer 1982. As part of the 
course, we had intended to study plankton community responses to different experimental conditions in 401 plastic bags incubated in situ. Because adequate supplies of alternative tubing were not available when we began our experiments, we used latex tubing to obtain samples from the submerged bags. The total length of tubing used was about $2 \mathrm{~m}$ with approximately $10 \mathrm{~cm}$ projecting into the bags. When phytoplankton populations rapidly declined in the bags, we decided to quantify the toxic effects of latex and other types of tubing on phytoplankton, zooplankton and bacteria.

Most toxicity tests to date have been primarily qualitative, where effects on phytoplankton growth have been categorized on a scale from 1 to 5. Only a few studies have examined short-term effects on processes such as photosynthesis. There have been limited tests using invertebrates such as sea urchin larvae and copepods (Bernhard et al. 1966, Bernhard 1977) but to our knowledge there have been no studies of the effects of contaminants from culture materials on bacterial growth. Toxicity tests have generally been conducted with phytoplankton cultures in liquid media (Blankley 1973, Payne \& Hall 1979) although agar plates have been used for bacteria and some pennate diatoms (Chan et al. 1980).

In this paper we report the effects of latex rubber, Tygon and silicone tubing on natural assemblages of phytoplankton, zooplankton and bacteria. The parameters that we used to assess the effects of the contaminants from the tubing were changes in phytoplankton growth rates and species composition, changes in bacterial production, and survival and fecundity of a copepod, Acartia clausii.

\section{MATERIALS AND METHODS}

Natural phytoplankton growth experiments. Natural phytoplankton were collected from a net tow $(40 \mu \mathrm{m}$ mesh size) beyond the dock at Friday Harbor, Washington. The concentrated sample, which was mostly chain-forming diatoms, was filtered through a $102 \mu \mathrm{m}$ mesh net to remove large grazers, diluted with seawater, and enriched with $75 \mu \mathrm{M} \mathrm{NO}_{3}{ }^{-}, 10 \mu \mathrm{M} \mathrm{PO}_{4}{ }^{-3}$ and $50 \mu \mathrm{M} \mathrm{SiO}_{4}{ }^{-4}$. Subsamples were taken from this large stock culture for experiments to examine the effect of latex, Tygon and silicone tubing on phytoplankton growth. The latex tubing was supplied by Van Waters \& Rogers, Seattle, and manufactured by Prime Line Industries (formerly Rubber Latex Products), Reichhold Chemicals Inc., Cuyahoga Falls, Ohio. The Tygon tubing was manufactured by Norton Plastics and Synthetic Div., Akron, Ohio, and the silicone tubing by Nalge Co., Division of Sybron Corp., Rochester, New York. All tubing was $0.64 \mathrm{~cm} \mathrm{I.} \mathrm{D.} \mathrm{and}$
$0.32 \mathrm{~cm}$ wall thickness. The condition of the tubing for the experiments was either new unwashed (referred to as unwashed), new and washed (referred to as washed) or 'aged' by soaking or autoclaving (referred to as aged).

To $200 \mathrm{ml}$ of culture in an Erlenmeyer flask, $0.1 \mathrm{~g}$ $(1 \mathrm{~mm})$ or $0.9 \mathrm{~g}(1 \mathrm{~cm})$ latex, $0.8 \mathrm{~g}(1 \mathrm{~cm})$ Tygon, $0.4 \mathrm{~g}$ $(1 \mathrm{~cm})$ silicone or no tubing was added. Cultures were grown under continuous fluorescent lighting at $170 \mu \mathrm{E}$ $\mathrm{m}^{-2} \mathrm{~s}^{-1}$ at $\sim 12^{\circ} \mathrm{C}$. In vivo chlorophyll a fluorescence was measured daily with a Turner model 111 fluorometer. Viable cells were counted and species identified using an inverted microscope, and where possible at least 200 cells of each species were counted. The slice of unwashed or washed tubing remained in the culture during the $5 \mathrm{~d}$ experiment.

A second growth-rate experiment with natural phytoplankton was set up to determine if the toxic components from the tubing could be removed by aging or autoclaving the tubing. Slices $(1 \mathrm{~mm})$ of latex, weighing approximately $0.1 \mathrm{~g}$, were cut and aged by soaking in filtered seawater for 1, 3 or $7 \mathrm{~d}$. Some slices were put in distilled water and autoclaved for $20 \mathrm{~min}$. Eleven sets of duplicate flasks were set up and $200 \mathrm{ml}$ of the natural phytoplankton stock culture described above was added to each flask. In the first 5 sets, a slice $(0.1 \mathrm{~g})$ of either unwashed, aged 1, 3 or $7 \mathrm{~d}$, or autoclaved latex tubing was added to the cuiture. In the 6 th, 7 th and 8 th sets, the culture was poured through a $1 \mathrm{~m}$ length of either unwashed latex or Tygon tubing, or washed Tygon tubing, and collected in a sterile flask. The 9th and 10th sets contained a $1 \mathrm{~cm}$ slice of unwashed or 1 wk soaked Tygon tubing and the last set was a control (no tubing). Fluorescence was measured daily for $4 \mathrm{~d}$ in order to monitor phytoplankton growth.

Growth of unialgal cultures. Unialgal cultures of 2 diatoms and 2 dinoflagellates were grown in the laboratory to test the toxic effects of different weights of latex tubing. Cultures of Skeletonema costatum, Thalassiosira pseudonana (clone 3H), Gymnodinium simplex and Prorocentrum minimum were obtained from the Northeast Pacific Culture Collection, Dept. of Oceanography, University of British Columbia, Vancouver. Phytoplankton were grown in natural seawater collected from the Pacific Environmental Institute, West Vancouver. The water was filtered through a Whatman GF/C filter and enriched with ES nutrients (Harrison et al. 1980). Forty $\mathrm{ml}$ of this seawater was dispensed into $50 \mathrm{ml}$ screw-cap test tubes, and duplicate tubes were inoculated with one of the 4 test species. Washed latex tubing, either 0.01 or $0.1 \mathrm{~g}$, was placed in each tube and growth was followed for 1 to 2 wk by measuring in vivo chlorophyll a fluorescence daily on a Turner Designs model 10 fluorometer. 
Cultures were grown at $17^{\circ} \mathrm{C}$ under continuous fluorescent lighting at an irradiance of $80 \mu \mathrm{E} \mathrm{m}^{-2} \mathrm{~s}^{-1}$.

Measurement of photosynthetic rates. Three Erlenmeyer flasks, each containing $200 \mathrm{ml}$ of the stock culture of natural phytoplankton, were incubated with $0.48 \mathrm{~g}$ washed Tygon, $0.60 \mathrm{~g}$ washed latex or no tubing. The culture was incubated at $11^{\circ} \mathrm{C}$ at $170 \mu \mathrm{E} \mathrm{m}^{-2} \mathrm{~s}^{-1}$. After 2 or $24 \mathrm{~h}$ exposure to the tubing, triplicate $10 \mathrm{ml}$ subsamples were added to sterile polystyrene culture tubes. To each tube, $0.39 \mu \mathrm{Ci}$ of $\mathrm{H}^{14} \mathrm{CO}_{3}^{-}$(Amersham) was added and incubated under the same conditions for $2 \mathrm{~h}$. These incubations were terminated by filtering the samples through $0.45 \mu \mathrm{m}$ Millipore filters. The filters were placed in a scintillation vial, acid fumed, dissolved in ethyl acetate and then counted by liquid scintillation (Beckman LS 7800).

Thymidine incorporation. The effects of latex and Tygon tubing on bacteria were assessed by measuring ${ }^{3} \mathrm{H}$-thymidine incorporation rate using the procedure of Fuhrman \& Azam (1980). Three $5 \mathrm{ml}$ seawater samples from the cultures described in the photosynthetic rate experiments were added to sterile polystyrene culture tubes. Samples were taken after $2 \mathrm{~h}$ exposure to the tubing and were incubated for $1 \mathrm{~h}$ with $5 \mathrm{nM}{ }^{3} \mathrm{H}$ thymidine ( $\mathrm{NEN}$; $80 \mathrm{Ci} \mathrm{mmol}^{-1}$ ). Formalin-killed controls were run for each treatment.

Zooplankton experiments. The effects of latex, Tygon, and silicone tubing on the survival, fecundity, and egg viability of contained zooplankton populations were investigated using the estuarine copepod Acartia clausii. The copepods were collected from Jakle's Lagoon, San Juan Island, Washington and maintained in the laboratory at $15^{\circ} \mathrm{C}$ with excess food for 1 wk prior to the experiment.

The experiment was conducted in $20 \mathrm{ml}$ plastic Petri dishes which were soaked in filtered seawater for $2 \mathrm{~d}$ and rinsed with distilled water before use. Ten replicates of each of 6 experimental treatments were prepared: silicone tubing with food, Tygon tubing with food, latex tubing with and without $(0.45 \mu \mathrm{m}$ filtered) food, and controls with and without food. Food consisted of a relatively dense mixture of the diatom Thalassiosira weissflogii and the prymnesiophyte Isochrysis galbana. Silicone and Tygon tubing were cut in doughnut-shaped slivers of 26.8 and $23.8 \mathrm{mg}$, respectively. Latex tubing slices were sectioned into cubes of $3.7 \mathrm{mg}$. All of the tubing pieces were new and soaked in filtered seawater for $8 \mathrm{~h}$ before use.

Three adult female Acartia clausii were placed initially in each Petri dish. The dishes were maintained at $15^{\circ} \mathrm{C}$ and constant light for $4 \mathrm{~d}$ ( $3 \mathrm{~d}$ for treatments without food). Additional food was not given. At daily intervals the contents of each dish were examined for numbers of live and dead copepods and numbers of eggs produced. Dead animals were removed. Eggs were removed and, together with all other eggs produced for a given experimental treatment, they were placed in a clean Petri dish with filtered seawater and no tubing. After $48 \mathrm{~h}$, sufficient time for all the eggs to have hatched at $15^{\circ} \mathrm{C}$ (Landry 1975), egg viability was determined by examining the dishes for numbers of hatched nauplii. Rates of fecundity were calculated by dividing the number of eggs produced by the number of females surviving the interval between observations, i.e. dead animals were assumed to have contributed nothing to egg production.

Extraction of latex tubing and GC/MS analysis. A piece of latex rubber tubing $(6.5 \mathrm{~g})$ was split lengthwise and then cut into $1 \mathrm{~cm}$ segments. The segments were placed in $100 \mathrm{ml}$ of $3 \% \mathrm{NaCl}$, the $\mathrm{pH}$ adjusted to 8.3 with $\mathrm{Na}_{2} \mathrm{CO}_{3}$ and the sample shaken for $2 \mathrm{~h}$. The tubing was removed and the water extracted at $\mathrm{pH} 10$ with three $15 \mathrm{ml}$ portions of methylene chloride $\left(\mathrm{CH}_{2} \mathrm{Cl}_{2}\right)$ in a separatory funnel. The $\mathrm{pH}$ of the aqueous layer was then adjusted to $\mathrm{pH} 2$ and the water re-extracted with $\mathrm{CH}_{2} \mathrm{Cl}_{2}$. A solution of $3 \% \mathrm{NaCl}$ at $\mathrm{pH}$

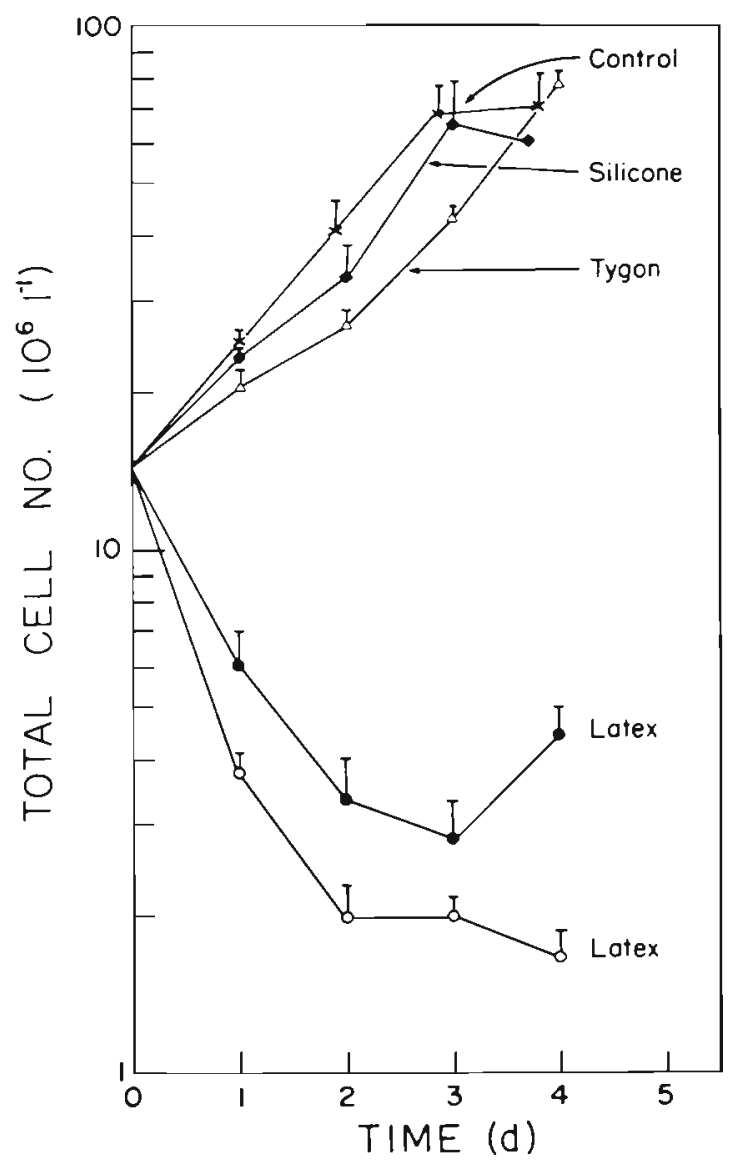

Fig.1. Change in total cell numbers in cultures of a natural phytoplankton assemblage containing: $1 \mathrm{~cm}$ latex tubing $(O)$; $1 \mathrm{~mm}$ latex tubing $(\bullet) ; 1 \mathrm{~cm}$ new Tygon tubing $(\Delta) ; 1 \mathrm{~cm}$ silicone tubing $(\uparrow)$; control $(\times)$. Error bars represent $\pm 1 \mathrm{SD}$; $=3$ 
Table 1. Number of cells at the beginning $\left(t_{0}\right)$ and after $4 \mathrm{~d}$ of growth in seawater containing various types of tubing (latex, Tygon and silicone) and various sized pieces (1 mm or $1 \mathrm{~cm}$ slice). Some estumates include $\pm 1 \mathrm{SD}$ where $\mathrm{n}=2$

\begin{tabular}{|c|c|c|c|c|c|c|}
\hline \multirow[t]{2}{*}{ Species } & \multicolumn{6}{|c|}{ Cell numbers $\left(10^{7}\right.$ cells $\left.1^{-1}\right)$} \\
\hline & $t_{0}$ & $\begin{array}{l}\text { Latex } \\
\text { (1 mm) }\end{array}$ & $\begin{array}{l}\text { Latex } \\
(1 \mathrm{~cm})\end{array}$ & $\begin{array}{c}\text { Tygon } \\
(1 \mathrm{~cm})\end{array}$ & $\begin{array}{c}\text { Silicone } \\
(1 \mathrm{~cm})\end{array}$ & Control \\
\hline Skeletonema costatum & 3.6 & 0.02 & Death & $23.0 \pm 0.2$ & 20.6 & $23.3 \pm 2.2$ \\
\hline Chaetoceros spp. & 2.8 & 0.04 & Death & $16.1 \pm 1.5$ & $16.5 \pm 0.9$ & $17.6 \pm 2$ \\
\hline Small Chaetoceros spp. $(<10 \mu \mathrm{m})$ & 3.9 & Death & Death & $6.5 \pm 3.1$ & $7.0 \pm 0.5$ & $9.6 \pm 2.6$ \\
\hline Eucampia zoodiacus & 0.7 & Death & Death & 0.48 & $1.04 \pm 0.1$ & 1.2 \\
\hline Leptocylindrus danicus & 0.24 & Death & Death & $4 \pm 2.1$ & $3.7 \pm 1$ & 4.1 \\
\hline Thalassiosira pacificus & 1.8 & 0.30 & 0.04 & $18.4 \pm 2.2$ & $15.3 \pm 2$ & $13.6 \pm 0.1$ \\
\hline Bodonid flagellates & 0.19 & 3.6 & 2.0 & $2.41 \pm 0.49$ & 2.0 & 3.5 \\
\hline Nitzschia pungens & 0.55 & Death & Death & 2.2 & $2.3 \pm 0.4$ & $2.0 \pm 0.1$ \\
\hline Nitzschia closterium & 0.4 & 0.06 & Death & $2.3 \pm 0.8$ & $2.3 \pm 0.3$ & $3.1 \pm 0.1$ \\
\hline Thalassiosira rotula & 0.27 & 0.44 & Death & $2.4 \pm 0.3$ & 2.0 & $1.31 \pm 0.2$ \\
\hline Thalassiosira nordenskioldii & 0 & 0.44 & 0.10 & 0.12 & 0.40 & 0.40 \\
\hline
\end{tabular}

8.3 was also extracted in the same manner. The extracts were dried over anhydrous $\mathrm{Na}_{2} \mathrm{SO}_{4}$ and concentrated in a Kuderna-Danish apparatus to $1 \mathrm{ml}$.

The extracts were analysed on a GC (HP $5880 \mathrm{~A}$ ) equipped with a $30 \mathrm{~m}$ DB-5 fused silica capillary column and an FID detector, temperature-programmed from 35 to $290^{\circ} \mathrm{C}$ at $8^{\circ} \mathrm{C} \mathrm{min}^{-1}$. The blank showed no interfering peaks.

The acid and base extracts were combined and the volume reduced to $0.2 \mathrm{ml}$ under $\mathrm{N}_{2}$ gas. The combined extract was submitted for GC/MS analysis on an HP $5985 \mathrm{~A}$ GC/MS with an electron impact ion source. The column was the same as for $\mathrm{GC}$ analysis. The oven temperature was programmed for 30 to $280^{\circ} \mathrm{C}$ at $10^{\circ} \mathrm{C}$ $\mathrm{min}^{-1}$. The flow rate was $20 \mathrm{~cm} \mathrm{~s}^{-1}$ linear velocity and He carrier gas was used.

\section{RESULTS}

Drastic decreases occurred in cell numbers in cultures of natural phytoplankton containing $1 \mathrm{~mm}$ or 1 $\mathrm{cm}$ of latex tubing (Fig. 1). Over a $4 \mathrm{~d}$ period most of the chain-forming diatoms such as Skeletonema costatum, Chaetoceros spp., Eucampia zoodiacus and Leptocylindrus danicus were killed by the presence of $1 \mathrm{~cm}$ of latex tubing (Table 1). More resistant species were Thalassiosira pacificus, $T$. rotula, $T$. nordenskioldii, and Nitzschia closterium (Table 1). The most resistant plankton were the bodonid flagellates which actually increased in numbers. The growth rate of cultures containing $1 \mathrm{~cm}$ of unwashed Tygon tubing was significantly $(\mathrm{p}<0.05)$ reduced $\left(\mu=0.5 \mathrm{~d}^{-1}\right)$ over the first $3 \mathrm{~d}$ compared to the control $\left(\mu=0.8 \mathrm{~d}^{-1}\right.$; Fig. 1). The presence of silicone tubing had no significant effect on the growth rate of the phytoplankton (Fig. 1).

All attempts to remove the toxic contaminants from

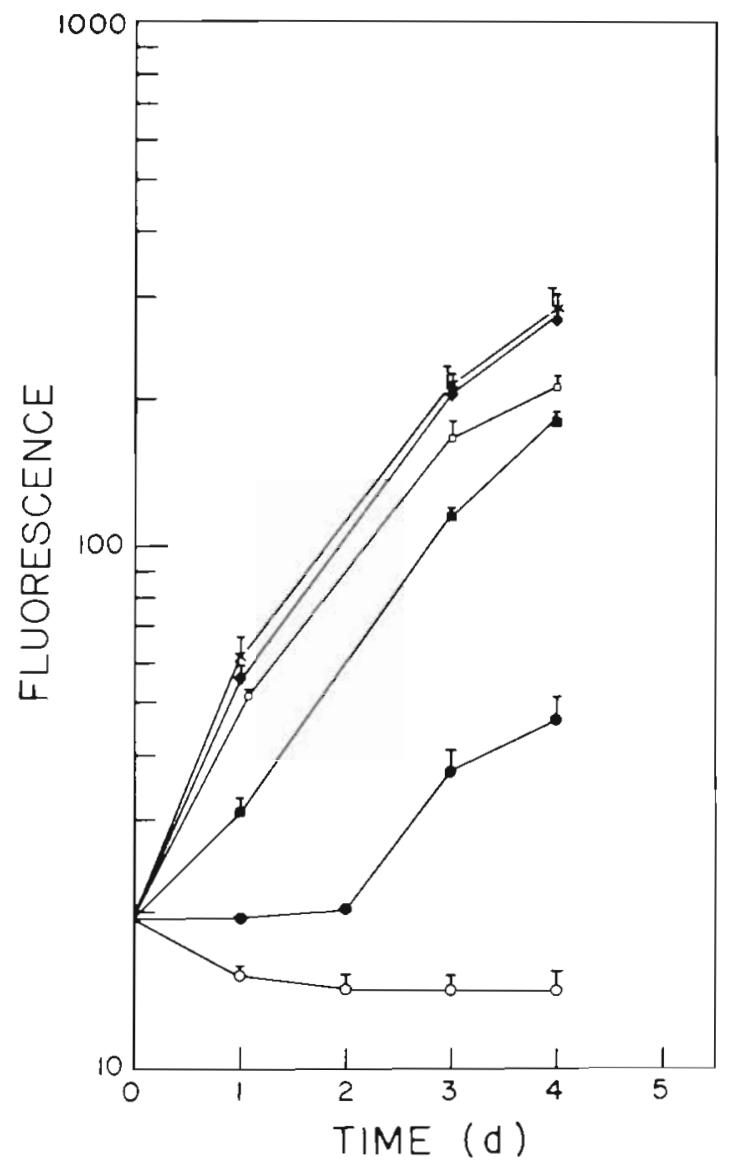

Fig. 2. Changes in relative fluorescence of a natural phytoplankton assemblage with time for cultures containing: $1 \mathrm{~mm}$ latex tubing aged for various times (see Materials and Methods') (0); $1 \mathrm{~cm}$ of unwashed Tygon tubing ( $)$; culture medium passed through $1 \mathrm{~m}$ of unwashed Tygon tubing ( $\boldsymbol{(}) ; 1$ $\mathrm{cm}$ of Tygon tubing soaked in distilled water for $1 \mathrm{wk}(\square)$; culture medium passed through $1 \mathrm{~m}$ washed (second pass through it) Tygon tubing $(x)$; control $(\bullet)$. Error bars represent

$$
\pm 1 \mathrm{SD} ; \mathrm{n}=3
$$




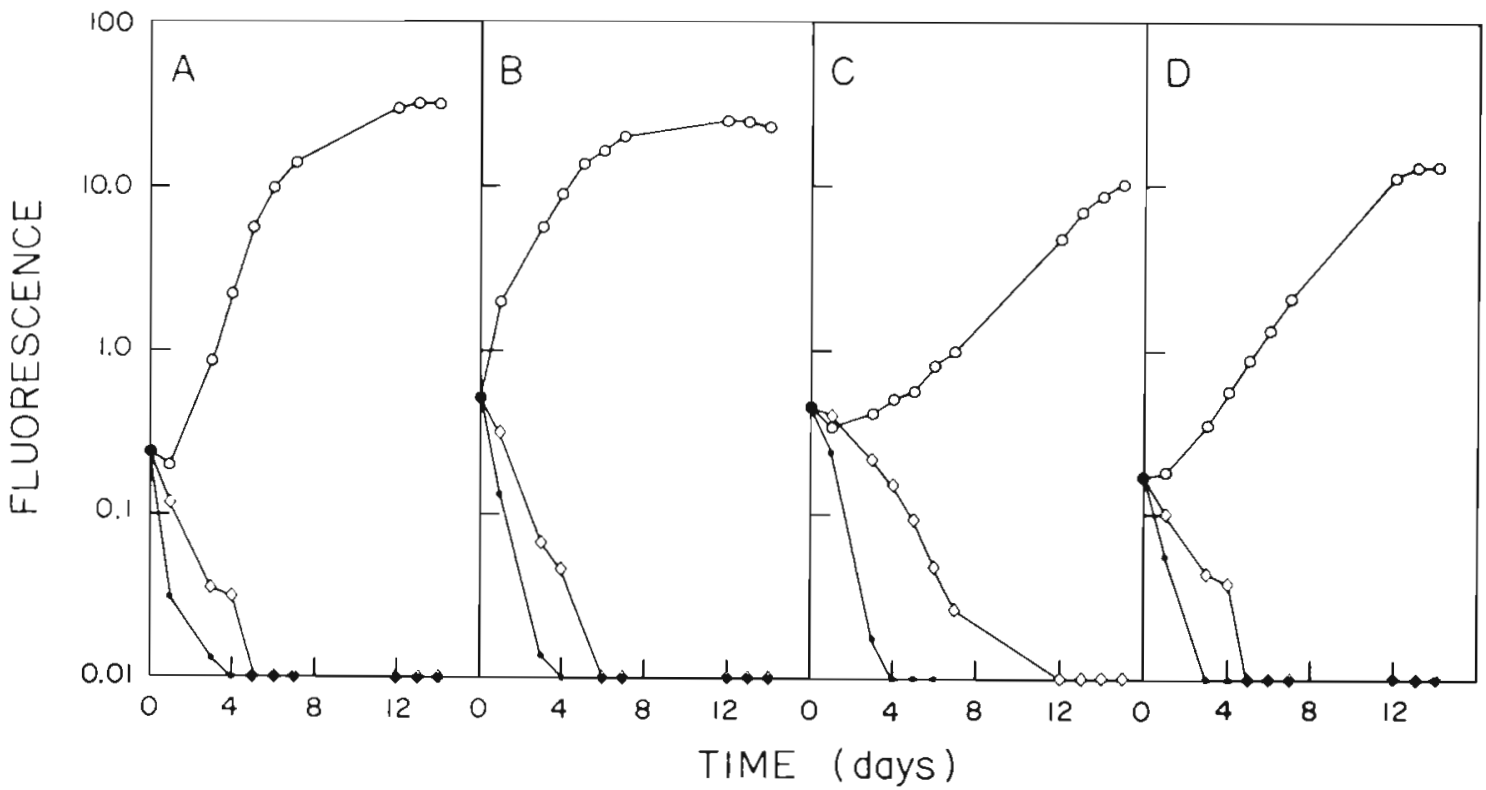

Fig. 3. (A) Skeletonema costatum, (B) Thalassiosira pseudonana, (C) Gymnodinium simplex, (D) Procentrum minimum. Changes in relative fluorescence with time for unialgal cultures containing $0.1 \mathrm{~g}(\bullet), 0.01 \mathrm{~g}(0)$, or $0 \mathrm{~g}$ (control) (O), of latex rubber tubing in the culture during the growth period, $\mathrm{n}=3$

latex tubing failed. Even though the latex rubber tubing changed color from amber to beige when it was aged in seawater for up to $1 \mathrm{wk}$, or autoclaved in distilled water for $20 \mathrm{~min}$, the toxic compounds were not removed. The fluorescence of the culture exposed to the aged tubing decreased over $4 \mathrm{~d}$ (Fig. 2). We were surprised to find that even pouring the culture through $1 \mathrm{~m}$ of latex tubing at the beginning of the experiment resulted in decreased fluorescence of similar magnitude to cultures containing a $1 \mathrm{~mm}$ slice of latex. When a $1 \mathrm{~cm}$ piece of unwashed Tygon tubing was placed in the culture, fluorescence was significantly decreased compared to the control. However, when a $1 \mathrm{~cm}$ piece of Tygon was soaked in seawater for $1 \mathrm{wk}$, it caused no inhibition of growth rate but the fluorescence of the culture on Day 4 was less than the control. Pouring the culture through $1 \mathrm{~m}$ of unwashed Tygon tubing caused a significant decrease in fluorescence, but when another culture was poured through the same tubing (i.e. the second pass through it) there was no significant effect on fluorescence.

In laboratory experiments with unialgal cultures, as little as $0.01 \mathrm{~g}$ of latex tubing (an order of magnitude less than was used for experiments with natural phytoplankton above) resulted in cell death in 5 to $12 \mathrm{~d}$ depending on the species (Fig. 3). Skeletonema costatum and Prorocentrum minimum were the most sensitive while Gymnodinium simplex was less sensitive.

In addition to the long-term effects on growth, latex and Tygon tubing caused a reduction in photosynthesis measured over short time scales. When cultures were exposed to latex or Tygon tubing for as little as $2 \mathrm{~h}$, a significant decrease in ${ }^{14} \mathrm{C}$ incorporation was observed (Fig. 4). However, if the culture was siphoned through a $1 \mathrm{~m}$ long piece of unwashed Tygon tubing before conducting the ${ }^{14} \mathrm{C}$ experiment, no significant effect was observed in ${ }^{14} \mathrm{C}$ incorporation (data not shown).

Short-term exposure $(2 \mathrm{~h})$ to latex and Tygon tubing significantly reduced $(\mathrm{p}<0.05){ }^{3} \mathrm{H}$-thymidine incorporation by bacteria. The amount of ${ }^{3} \mathrm{H}$-thymidine incorporated ( $\pm 1 \mathrm{SD}$ ) by the controls (25263 $\pm 485 \mathrm{cpm}$; $\mathrm{n}$

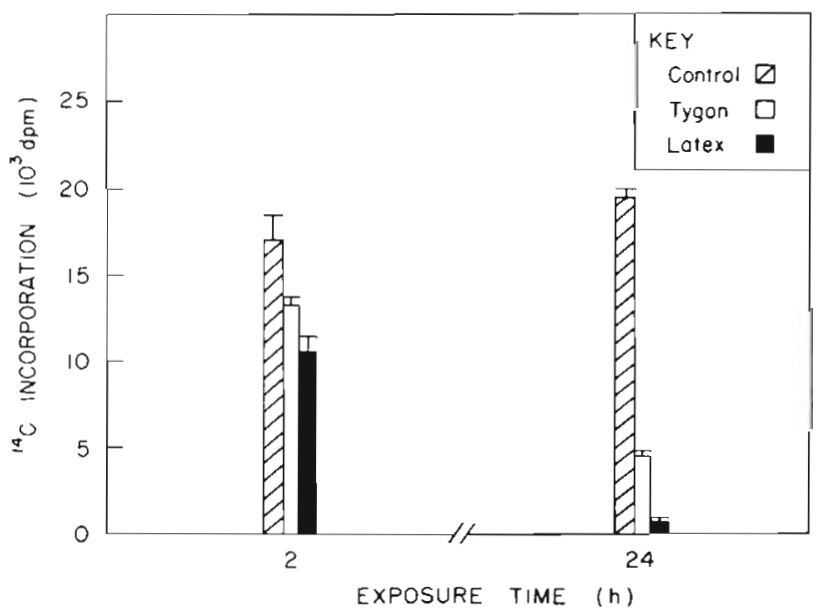

Fig. 4. Effect of $1 \mathrm{~cm}$ of latex or Tygon tubing placed in cultures of natural phytoplankton, on the incorporation of ${ }^{14} \mathrm{C}$ ( $2 \mathrm{~h}$ incubations) when cultures were exposed to the tubing for 2 or $24 \mathrm{~h}$. Error bars represent $\pm 1 \mathrm{SD} ; \mathrm{n}=3$ 
= 3) was greater than for the latex $(7891 \pm 424 \mathrm{cpm}$; $=3$ ) and Tygon (19092 $0265 \mathrm{cpm} ; \mathbf{n}=2)$ treatments. The quenching by the samples was identical for the 3 treatments. Longer-term toxicity experiments ( 2 to 4 d) showed greater numbers of bacteria in latex than in control cultures; these cells were also larger (data not shown).

Survival of Acartia clausii was substantially lower in the presence of latex and Tygon tubing than with silicone tubing or in controls (Fig. 5A). All copepods incubated with latex tubing died within $4 \mathrm{~d}$ following an approximately linear decline with time. Mortality of copepods exposed to Tygon was $70 \%$ for the same time period and $37 \%$ for control and silicone tubing treatments. Initial survival of the copepods in latex treatments without food was similar to the controls and was much better than the latex treatment with food (Fig. 5B). This suggests that the toxic compounds in the rubber may be incorporated more rapidly when the copepods feed. After 3 d however, the effects of latex tubing on copepod mortality were comparable with and without food.

Fecundity of Acartia clausii was significantly reduced by all tubing treatments relative to controls with food (Table 2). Of the treatments with food, fecundity in the presence of latex was most affected: total egg production per surviving female was less than half that for food controls and similar to controls without food. Although short-term survival of the copepods in the latex treatment without food was higher than the treatment with food, fecundity was markedly reduced.

From previous studies of Acartia clausii in Jakle's Lagoon, a maximum fecundity of about $15 \mathrm{eggs}^{-1}$ is expected at $15^{\circ} \mathrm{C}$ for late summer-collected females (Landry 1978). This level was approached only on the first day of the experiment in control containers with added food. It is not known why egg production declined for all treatments over the $4 \mathrm{~d}$ of observation. Possible explanations are food limitation or the advanced age of the specimens.

Egg viability of copepods exposed to silicone and in controls were comparable $(82.7$ and $78.1 \%$, respectively; Table 2), but in comparison, the Tygon and latex treatments substantially reduced egg viability (58.4 and $45.6 \%$, respectively).

The effects of silicone, Tygon and latex tubing on the number of nauplii produced by 30 females in each treatment over the $4 \mathrm{~d}$ period are represented in Fig. 6. The reduced production in the silicone treatment relative to the control is entirely due to differences in fecundity for the first $2 \mathrm{~d}$ of the experiment. It is not clear why silicone affected egg production but not female survival or egg viability. Both the Tygon and latex treatments differed from controls in all 3 mea-

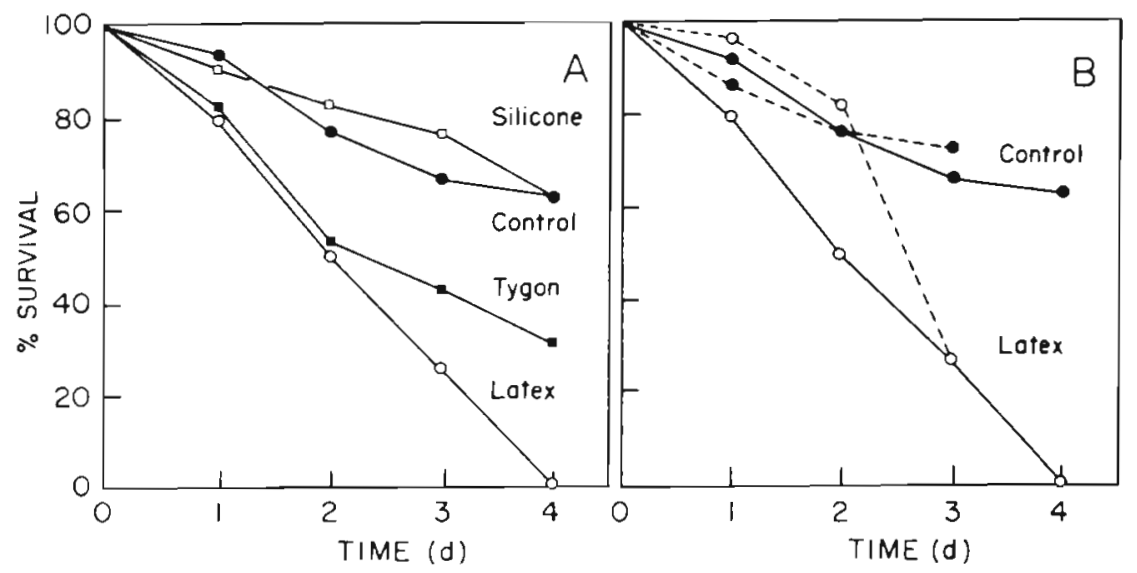

Fig. 5. Acartia clausi. (A) Effects of silicone, Tygon and latex tubing on the survival of adult females. Percentage survival is based on an initial 30 individuals per treatment. Food was present for all treatments. ( $\square$ ) Silicone; $(\bullet)$ control; (a) Tygon; (O) latex. (B) Effects of feeding $(-)$ versus no feeding $(--)$ on the survival of females in the presence

$(O)$ and absence ( $)$ of latex tubing

Table 2. Effects of silicone, Tygon, and latex tubing on the fecundity and egg viability of the copepod Acartia clausii. Fecundity is expressed as mean numbers of eggs produced female $e^{-1} \mathrm{~d}^{-1}$ (SD). 'Total refers to the cumulative number of eggs produced female $\mathrm{e}^{-1}$ for the period of observation; 3 or $4 \mathrm{~d}$. Percentage viability is obtained from the number of nauplii successfully hatching from all eggs collected

\begin{tabular}{|c|c|c|c|c|c|c|}
\hline Treatment & Day 1 & Day 2 & Day 3 & Day 4 & Total & $\%$ Viability \\
\hline Control & $13.4(3.3)$ & $8.4(4.3)$ & $4.8(1.8)$ & $4.7(2.2)$ & $31.1(4.8)$ & 78.1 \\
\hline Silicone & $7.3(1.8)$ & $4.3(3.0)$ & $3.8(1.5)$ & $3.8(2.1)$ & $19.2(5.3)$ & 82.7 \\
\hline Tygon & $8.9(4.3)$ & $5.3(3.5)$ & $6.2(2.6)$ & $3.9(3.8)$ & $22.2(9.7)$ & 58.4 \\
\hline Latex & $9.5(3.4)$ & $4.2(4.4)$ & $1.0(2.0)$ & - & $14.6(5.2)$ & 45.6 \\
\hline Control (no food) & $5.6(2.4)$ & $4.1(1.9)$ & $3.0(1.7)$ & - & $12.7(3.2)$ & \\
\hline Latex (no food) & $5.8(1.6)$ & $0.7(1.1)$ & $0.1(0.2)$ & - & $6.6(1.6)$ & \\
\hline
\end{tabular}




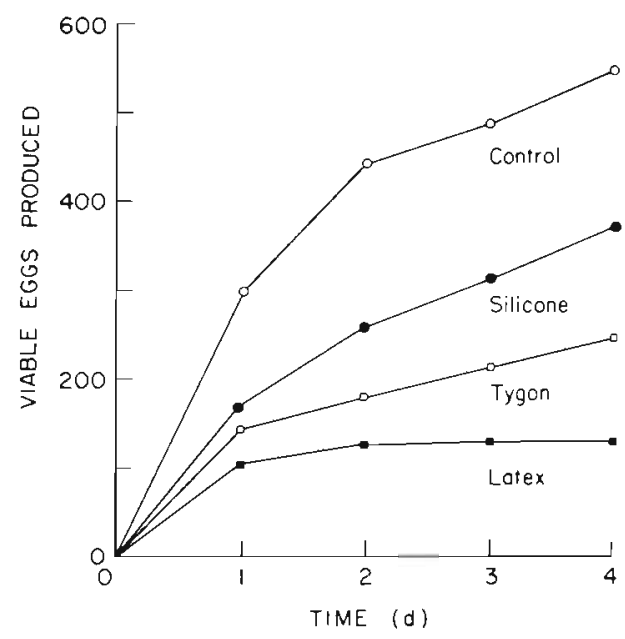

Fig. 6. Acartia clausii. Effects of silicone, Tygon and latex tubing on the number of nauplii produced by 30 females. Results represent the cumulative effects of the treatments on female survival, fecundity and egg viability. (O) Control; (•) silicone; ( $\square$ ) Tygon; ( $\square$ ) latex

sured parameters. Latex clearly had the most toxic impact of the 3 tubings tested despite the fact that, by weight, 6 to 7 times the amount of silicone and Tygon were used.

The GC/MS analysis of the latex tubing extract revealed that it contained aliphatic saturated hydrocarbons $\left(\mathrm{C}_{n} \mathrm{H}_{2 n+2}\right)$, substituted napthalenes and aliphatic fatty acids. Subsequent analysis of the latex tubing with Kratos MS-80 RFA GC/MS suggested that the toxicity of the latex tubing was probably due to penta and tetrachlorophenols found in a ratio of about 10:1. Details of other compounds found in the tubing are given elsewhere (Eigendorf et al. unpubl.).

\section{DISCUSSION}

\section{Latex tubing}

Latex tubing was the most toxic to phytoplankton, zooplankton and bacteria of the 3 types of tubing that were tested. Pieces as small as $0.1 \mathrm{~g}$ killed phytoplankton (algicidal) from natural communities in just a few days. Some centric diatoms (e.g. Skeletonema costatum, Chaetoceros spp., Leptocylindrus danicus and Eucampia zoodiacus) were particularly sensitive while other centrics (e.g. Thalassiosira spp.) were noticeably less sensitive. Pennate diatoms (e.g. Nitzschia spp.) and bodonid flagellates were the most resistant organisms. When natural phytoplankton cultures containing $1 \mathrm{~mm}$ of latex tubing were left for $14 \mathrm{~d}$, Nitzschia spp. completely dominated the cultures at the end of this time period. These observations agree generally with results on the toxicity of a mixture of heary metals to a natural phytoplankton assemblage. In these studies Thalassiosira spp. and Nitzschia spp. were found to be more resistant to the metal mixture than Chaetoceros spp. (Hollibaugh et al. 1980, Thomas et al. 1980).

We knew from previous reports that latex tubing was toxic (Davis et al. 1953, Dyer \& Richardson 1962, Bernhard \& Zattera 1970) but we did not realize that it was extremely toxic until we saw the results of our experiments. It was surprising to find that even a piece as small as $0.01 \mathrm{~g}$ in $40 \mathrm{ml}$ of seawater killed cells and especially that pouring seawater through a length of tubing $1 \mathrm{~m}$ long rendered the seawater toxic. Attempts to remove the contaminants by soaking or autoclaving the tubing in water were unsuccessful. This suggests that the compounds are very toxic in small quantities and that they are only slightly water-soluble and continue to leach out of the tubing for long periods.

The GC/MS chromatogram of extracted compounds indicated the most likely compounds causing the toxicity were penta and tetrachlorophenols. The toxicity of these compounds is well known (Cantelmo \& Rao 1978, Huber et al. 1982), but we were surprised to find them in tubing since they are usually associated with wood products such as plywood. In these products, these compounds are used as a wood preservative, insecticide and herbicide (Poole et al. 1978). Recent investigations with latex rubber gloves have shown that the hydrophilic fraction of the latex contains compounds which are skin irritants (Adolf \& Hecker 1984, Shmunes \& Darby 1984). Other studies have shown that latex rubber tubing and rubber stoppers contain large amounts of zinc and smaller amounts of copper (Robertson 1968, Bernhard 1977, Bogden et al. 1983). Since our seawater was enriched with a nutrient enrichment solution containing EDTA (EDTA: trace metals $=1.6$ ), it is unlikely that the toxicity was due to heavy metals such as zinc because the excess EDTA should have chelated the zinc rendering it non-toxic.

There are different manufacturers of latex tubing (e.g. Reichold Chemicals Inc., Kent Latex Products, Ohio and Nir Lat Industries, Israel) and the tubing is advertised under different descriptions. Most commonly it is referred to as natural latex tubing, amber rubber tubing, or surgical rubber tubing. The most common manufacturer is Reichold Chemicals Inc. and their tubing is distributed by Van Waters and Rogers, Sargent-Welch, Thomas Scientific, and Fisher Scientific. Some tubing is described as non-toxic (e.g. Nir Lat Industries, Israel) but we did not test this tubing.

To our knowledge, the toxicity of latex tubing has been tested on only 2 invertebrates: a copepod, Euterpina acutifrons, and sea urchin larvae, Arbacia lixula, (Bernhard \& Zattera 1970, Bernhard 1977). These studies found that materials such as natural rubber and 
PVC tubing which were very toxic to algae were less toxic to the copepod and not toxic to sea urchin larvae. Toxicity was tested in terms of survival time for adult copepods in their experiments. In our experiments latex tubing decreased the survival, fecundity and egg viability of the copepod Acartia clausii. Survival was lower when the copepods had food, suggesting that the toxic compounds may be incorporated more rapidly when the copepods feed. Similar observations were made by Nassogne (1972) on the copepod Euterpina acutifrons and showed that the food (algae) was an important transport vehicle of toxic organic substances.

There have been no studies on the toxicity of any of the common culture materials on bacterial growth and production. Our results indicate that bacteria are as sensitive as phytoplankton.

\section{Tygon tubing}

Tygon is the trade name for polyvinyl chloride tubing and there are at least 2 grades: regular (R-3603) and surgical ( $\mathrm{S}-50 \mathrm{HL}$ ). This tubing is generally considered to be non-toxic to phytoplankton (Dyer \& Richardson 1962, Bernhard et al. 1966, Bernhard \& Zattera 1970, Justice et al. 1972, Bernhard 1977) even though it contains phthalate esters that can contaminate culture media (Kordan 1965, Marx 1972). These phthalate esters appear to be toxic to phytoplankton only at high concentrations (Bernhard 1977). This situation might arise where a large amount of Tygon tubing is in contact with a small volume of water. One early report indicated that exposure to a piece of Tygon reduced the photosynthetic rate $\left({ }^{14} \mathrm{C}\right.$ fixation) of a natural assemblage of phytoplankton by $50 \%$ (Doty \& Oguri 1959). Recently, experiments with germlings of the seaweeds Fucus spiralis and $F$. vesiculosis showed that tubing which appears to be similar to Tygon (Portex vinyl surgical tubing Shore 80 ) affected the growth rate of these seaweeds, but soaking the tubing before use reduced the inhibitory effect (Schonbeck \& Norton 1980). These results agree with our observations, that new, unwashed Tygon tubing reduced the growth of phytoplankton but this effect could be eliminated by rinsing the tubing. The inside of Tygon tubing is frequently dusted to keep it from sticking together (Dyer \& Richardson 1962). It is possible that this dust might be the toxic substance since the toxic effect is easily removed with washing.

The effect of Tygon tubing on bacterial growth and metabolism has not been studied before. Our results on ${ }^{3} \mathrm{H}$-thymidine suggest that considerable caution must be exercised in the use of Tygon tubing in bacterial studies.
The effect of Tygon on the survival time of the copepod Euterpina acutifrons has been studied and was found to exert no effect (Bernhard \& Zattera 1970). This is in contrast to our results with $A$. clausii where exposure to washed Tygon decreased survival, fecundity and egg viability.

\section{Silicone tubing}

We found that silicone did not affect phytoplankton, zooplankton or bacterial growth or survival. Therefore it is the safest but the most expensive tubing to use in plankton sampling and experimentation.

Bernhard \& Zattera (1970) tested the effect of silicone tubing and silicone glue (SE 1201 translucent) on the growth of 2 centric marine diatoms, a dinoflagellate and a coccolithophorid. These materials were found to be non-toxic before and after autoclaving. Dyer \& Richardson (1962) found that silicone rubber (DowCorning Inc.), which was room-temperature vulcanized, was inhibitory to freshwater phytoplankton, while silicone tubing (Medical Grade X-30 146) showed no inhibition. There has been a report that new silicone tubing had no effect on the growth rate of Anabaena variabilis, but when the tubing was autoclaved and used several times it became toxic (Healey \& Hendzel 1975). There are no reports on the effect of silicone on bacteria and in the only investigation of the survival of a copepod, silicone was shown to be nontoxic (Bernhard \& Zattera 1970).

\section{CONCLUSIONS}

From this study, we recommend that latex tubing should not be used, even incidentally, in any experimental work involving live plankton. Furthermore, we suggest that many historical rate measurements on plankton samples collected with conventional Van Dorn and Niskin bottles with internal latex springs might be biased (underestimates) as a result of contamination by the toxic rubber. Tygon tubing, which is generally safe, may exhibit inhibitory effects under some circumstances. Bernhard was the first to alert the scientific community 20 yr ago to the inhibitory effect of some culture materials by testing over 50 different materials on phytoplankton and zooplankton (Bernhard et al. 1966, Bernhard \& Zattera 1970, Bernhard 1977). However, concern is still being raised today over the use of toxic materials for the culture and collection of plankton especially as we attempt to study and grow the more sensitive oceanic species. 
Acknowledgements. This research was supported by the Natural Sciences and Engineering Research Council of Canada and the National Science Foundation, USA. We thank V Fagerness, B. Monger, School of Oceanography, University of Washington; and P. Parkinson, Department of Civil Engineering, University of British Columbia, for technical assistance. M. Petelycky conducted the laboratory experiments with the unialgal cultures.

\section{LITERATURE CITED}

Adolf, W., Hecker, E. (1984). On the active principles of the spurge family, $X$. Skin irritants, cocarcinogens, and cryptic cocarcinogens from the latex of the manchineel tree. J. Nat. Prod. 47: 482-496

Bernhard, M. (1977). Chemical contamination of culture media: assessment, avoidance and control. In: Kinne, $O$. (ed.) Marine ecology, Vol. III, Cultivation Part 3. Wiley \& Sons, Chichester, p. 1459-1499

Bernhard, M., Zattera, A. (1970). The importance of avoiding chemical contamination for a successful cultivation of marine organisms. Helgoländer wiss. Meeresunters., 20: $655-675$

Bernhard, M., Zattera, A., Filesi, P. (1966). Suitability of various substances for use in the culture of marine organisms. Pubbl. Staz. zool. Napoli 35: 89-104

Blankley, W. F. (1973). Toxicity and inhibitory materials associated with culturing. In; Stein, J. R. (ed.) Handbook of phycological methods. I. Culture methods and growth measurements. Cambridge University Press, New York, p. 207-229

Bogden, J. D., Zadzielski, E., Aviv, A. (1983). Extraction of copper and zinc from rubber and silicone stoppers. J. Toxicology Environ. Health 11: 967-969

Brooks, R. (1969). Properties of materials suitable for the cultivation and handling of micro-organisms. In: Norris, J. R., Ribbons, D. W. (ed.) Methods in microbiology 1. Academic Press, New York, p. 21-75

Cantelmo, F. R., Rao, K. R. (1978). Effect of pentachlorophenol (PCP) on meiobenthic communitjes established in an experimental system. Mar. Biol. 46: 17-22

Chan, A. T., Andersen, R. J., LeBlanc, M. J., Harrison, P. J. (1980). Algal plating as a tool for investigating allelopathy among marine microalgae. Mar. Biol. 59: 7-13

Davis, E. A., Dedrick, J., French, C. S., Milner, H. W., Myers, J., Smith, J. H. C., Spoehr, H. A. (1953). Laboratory experiments on Chlorella culture at The Carnegie Institution of Washington, Dept. of Plant Biology. In: Burlew, J. S. (ed.) Algal culture from laboratory to pilot plant. Carnegie Inst. Wash. Publ. No. 600, Washington, D. C., p. 105-153

Doty, M. S., Oguri, M. (1959). The carbon-fourteen technique for detemining primary plankton productivity. Pubbl. Staz. zool. Napoli 31: 70-94

Dyer, D. L., Richardson, D. E. (1962). Materials of construction in algal culture. Appl. Microbiol. 10: 129-131

Fuhrman, J. A., Azam, F. (1980). Bacterioplankton secondary production estimates for coastal waters of British Columbia, Antarctica and California. Appl. environ. Microbiol. 39: 1085-1095
Harrison, P. J., Waters, R. E., Taylor, F. J. R. (1980). A broad spectrum artificial seawater medium for coastal and open ocean phytoplankton. J. Phycol. 16: 28-35

Healey, F. P., Hendzel, L. L. (1975). Effect of phosphorus deficiency on two algae growing in chemostats. J. Phycol. 11: 303-309

Hollibaugh, J. T., Seibert, D. L. R., Thomas, W. H. (1980). A comparison of the acute toxicities of ten heavy metals to phytoplankton from Saanich Inlet, B. C., Canada. Estuar coast mar. Sci. 10: 93-105

Huber, W. Schubert, V., Sautter, C. (1982). Effects of pentachlorophenol on the metabolism of the aquatic macrophyte Lemna minor L. Environ. Pollut. (Series A) 29: 215-223

Justice, C., Murray, S., Dixon, P. S., Scherfig, J. (1972). Evaluation of materials for use in algal culture systems. Hydrobiologia 40: 215-221

Kordan, H. A. (1965). Fluorescent contaminants from plastic and rubber laboratory equipment. Science (Wash., D. C.) 149: $1382-1383$

Landry, M. R. (1975). Seasonal temperature effects and predicting developmental rates of marine copepod eggs. Limnol. Oceanogr. 20: 434-440

Landry, M. R. (1978). Population dynamics and production of a planktonic marine copepod, Acartia clausii, in a small temperate lagoon on San Juan Island, Washington. Int. Rev. ges. Hydrobiol. 63: 77-119

Marx, J. L. (1972). Phthalic acid esters: biological impact uncertain. Science (Wash., D. C.) 178: 46-47

Nassogne, A. (1972). First heterotrophic level of the food chain. In: Bernhard, M. (ed.). Studies on the radioactive contamination of the sea. Annual Report, 1971, of the laboratoria, per lo Studio della Contaminazione Radioattiua del Mare CNEN-EURATOM, Fiascherino, La Spezia, Italy, EUR, $4701 \mathrm{e}$

Payne, A. G., Hall, R. H. (1979). A method for measuring algal toxicity and its application to the safety assessment of new chemicals. In: Marking, L. L., Kimerle, R. A. (ed.) Aquatic toxicology. ASTM STP 667, American Society for Testing and Materials, Philadelphia, p. 171-180

Poole, N. J., Wildish, D. J., Kristmanson, D. D. (1978). The effects of the pulp and paper industry on the aquatic environment. CRC Crit. Rev. environ. Control 10: 153-195

Robertson, D. E. (1968). Role of contamination in trace element analysis of sea water. Analyt. Chem. 40: 1067-1072

Ryther, J. H., Guillard, R. R. L. (1962). Studies of marine planktonic diatoms. II. Use of Cyclotella nana Hustedt for assays of vitamin $B_{12}$ in seawater. Can. J. Microbiol. 8: $437-445$

Schonbeck, M. W., Norton, T. A. (1980). The effects on the growth of fucoid algae of some synthetic materials used in the construction of culture apparatus. Botanica mar. 23: $433-434$

Shmunes, E., Darby, T. (1984). Contact dermatitis due to endotoxin in irradiated latex gloves. Contact Dermatitis 10: $240-244$

Thomas, W. H., Hollibaugh, J. T., Seibert, D. L. R., Wallace, G. T., Jr., (1980). Toxicity of a mixture of ten metals to phytoplankton. Mar. Ecol. Prog. Ser. 2: 213-220

This article was presented by Professor R. Y. Morita; it was accepted for printing on September 5, 1986 